\title{
Determining the Relationship of Parents, Knowledge and Attitudes and Health Literacy About the Admission or Refusal of Childhood Immunization
}

\section{Ebeveynlerin Çocukluk Çağı Aşılarının Kabulünün Sağlık Okuryazarlığı ile Illişkisi}

\author{
Figen Yıldızeli'(iD), Derya Alabaz'(iD), Ebru Gözüyeşil2(iD) \\ 1 Division of Pediatric Infectious Diseases, Department of Pediatrics, Çukurova University Faculty of Medicine, Adana, Turkey \\ 2 Department of Midwifery, Çukurova University Faculty of Health Sciences, Adana, Turkey
}

Cite this article as: Yıldızeli F, Alabaz D, Gözüyeşil E. Determining the relationship of parents, knowledge and attitudes and health literacy about the admission or refusal of childhood immunization. J Pediatr Inf 2021;15(2):e88-e96.

\section{Abstract}

Objective: This research was conducted to determine the knowledge and attitudes of parents about vaccine acceptance or rejection and to evaluate their relationship with health literacy.

Material and Methods: This descriptive study was conducted with the parents of 220 pediatric patients who were admitted to the pediatric and pediatric infection outpatient clinic/service of Çukurova University Balcalı Hospital. The data were collected by using Personal Information Form and Health Literacy Scale.

Results: The mean age of the mothers was $30.20 \pm 5.89$, and the average health literacy score was $106.80 \pm 17.4$. A statistically significant difference was found between the variables of education status $(p<0.001)$, employment status $(p=0.005)$, social security status $(p<0.001)$, the number of children $(p<0.001)$, their knowledge and attitudes about vaccination $(p=$ 0.004 ), the status of paid vaccination for their children, the reason for not having paid vaccinations $(p=0.004)$, and the total score averages of the health literacy scale.

Conclusion: In this study, it was determined that the vast majority of mothers accepted vaccines and the health literacy levels of the mothers were sufficient. Besides, the health literacy levels of the mothers were affected by education status, income status, employment status of the mother, social security status, the number of children, the status of paid vaccination for their children, the reason for not having paid vaccinations.

Keywords: Vaccination, child, parent, health literacy
Öz

Giriş: Bu araştırma, aşı kabulü veya reddi hakkında anne/babaların bilgi ve tutumlarını belirlemek ve bunların sağlık okuryazarlığı ile ilişkisini değerlendirmek amacıyla yürütülmüştür.

Gereç ve Yöntemler: Tanımlayıcı tipteki bu araştırma, Çukurova Üniversitesi Balcalı Hastanesi Çocuk Sağlığı ve Hastalıkları Polikliniği ile Çocuk Enfeksiyon Poliklinik/Servisine başvuran 220 çocuk hastanın ebeveynleriyle yürütülmüştür. Araştırma verileri Kişisel Bilgi Formu ve Sağlık Okuryazarlığı Ölçeği ile toplanmıştır.

Bulgular: Annelerin yaş ortalaması $30.20 \pm 5.89$, sağlık okuryazarlığı toplam puan ortalaması ise $106.80 \pm 17.4$ olarak saptanmıştır. Annelerin eğitim durumu $(p<0.001)$, çalışma durumu $(p=0.005)$, sosyal güvence durumu $(p<0.001)$, çocuk sayısı ( $p<0.001)$, çocuklarına ücretli aşı yaptırma durumu $(p=0.004)$ ve çocuklarına ücretli aşı yaptırmama nedeni değişkenleri ( $p=0.004)$ ile sağlık okuryazarlığı ölçeği toplam puan ortalamaları arasında istatistiksel olarak anlamlı farklılık saptanmıştır.

Sonuç: Bu araştırmada annelerin büyük çoğunluğunun aşıları kabul ettiği ve annelerin sağlık okuryazarlığı düzeylerinin yeterli olduğu saptanmıştır. Ayrıca annelerin sağlık okuryazarlık düzeylerinin eğitim durumu, gelir durumu, annenin çalışma durumu, sosyal güvence durumu, çocuk sayısı, ücretli aşı yaptırma durumu ve ücretli aşı yaptırmama nedenleri değişkenlerinden etkilendiği belirlenmiştir.

Anahtar Kelimeler: Aşı, çocuk, ebeveyn, sağlık okuryazarlığı

\section{Correspondence Address/Yazışma Adresi}

\section{Figen Yıldızeli}

Çukurova Üniversitesi Tıp Fakültesi,

Çocuk Sağlığı ve Hastalıkları Anabilim Dalı,

Çocuk Enfeksiyon Hastalıkları Bilim Dalı,

Adana-Türkiye

E-mail: figenyildizeli74@gmail.com 


\section{Introduction}

Immunization is one of the most effective, reliable, and economic ways to protect the public from infectious diseases (1), and the main objective is to prevent disabilities, deaths, and the occurrence of vaccine-preventable diseases particularly in infants and children (2). According to the data of World Health Organization (WHO), over 100 million children get vaccinated before the age of 1 year thanks to vaccine implementations, and 2.5 million children avoid death each year (3).

As of 2018, vaccination rates are $90 \%$ in Europe and the USA and around $70-80 \%$ in countries like Afghanistan, Nigeria, Pakistan, and India (2). Regarding the 2017 data, vaccination rates diminished in Turkey, the rates, which were 98\% in 2016, dropped to $96 \%$ in 2017 (4). The number of families that refuse to get their children vaccinated was 183 in 2011, and in 2018, this number reached to the level of 23 thousand (4). In a study conducted in Turkey, it has been reported that $3 / 10$ of young females with high socioeconomic levels refuse vaccination or are irresolute (5).

Health Literacy (HL) is the ability to appreciate many healthy actions related to health. WHO has defined $\mathrm{HL}$ as "the capacity to obtain, understand and use basic health information to protect and sustain health" (6).

Information on vaccines is complicated, and thus some degree of literacy and logic is needed to understand this information. If health literacy level of the patients is low, it becomes more difficult to explain vaccines. Particularly social media, constantly increasing information pollution and not being able to reach correct information can be considered as a potential determinant in experiencing vaccine hesitations (7).

When the literature is reviewed, it is observed that there have been many studies conducted in the world and in our country on vaccination acceptance or refusal (8-10), but there are very few studies investigating the relation between vaccine acceptance or refusal and HL. In studies carried out on immunization rates, it has been determined that young age, incomplete and incorrect information, education, low socioeconomic and sociocultural status negatively affect immunization rates. Besides, it has also been stated that families with high socioeconomic level have started refusing vaccines or remained irresolute on the matter in recent years in developed countries and in our country (11-14).

Influential interaction with the parents can be an efficient method in overcoming anti-vaccination. The positive effect of correct, reliable and influential methods in enabling communication has been emphasized in studies on vaccines and drugs (7). In addition, informing parents on vaccines and their effects and the comprehension and interpretation of these information by the parents are highly important (15). Therefore, it is possible to indicate that the level of $\mathrm{HL}$ is crucial in experiencing vaccine acceptance or refusal.

It is speculated by this study that an important gap will be filled and a basis for the steps to be taken will be provided in understanding mothers who accept, refuse, or show hesitancy towards vaccines. Moreover, this study was also carried out due to the fact that studies investigating the relation between vaccine acceptance or refusal and $\mathrm{HL}$ are scant and that the knowledge and attitudes of mothers having children aged between 0-5 years regarding vaccine acceptance or refusal should be determined and their relation with $\mathrm{HL}$ should be evaluated.

\section{Materials and Methods}

\section{Research Type}

This research has a descriptive design.

\section{The Place and Duration of Research}

The research was conducted with the mothers of child patients presenting to Çukurova University, Balcalı Hospital, Pediatric Health and Pediatric Infectious Diseases Polyclinics between 15 November 2019 and 15 January 2020.

\section{Research Population and Sample}

The research population comprised 480 mothers who had children aged 0-5 years presenting to Çukurova University, Balcalı Hospital, Pediatric Health and Pediatric Infectious Diseases Polyclinics. Considering the number of mothers meeting research criteria and presenting to relevant departments, simple random sampling was performed and the research was carried out with 220 mothers.

The research included mothers aged 18 years and over with good communication skills in Turkish and children aged 0-5 years. Mothers who were foreigners and immigrants, mothers with problems in communication and those with mental incapacity were excluded.

\section{Data Collection Form and Methods}

Research data were collected with personal information form and Health Literacy Scale (HLS).

\section{Personal Information Form}

The personal information form is a form consisting 33 questions regarding sociodemographic features of the mothers and their knowledge and attitudes on vaccines, which was prepared by the researchers themselves in line with literature data (1,8,16-18).

\section{Health Literacy Scale}

The HLS-EU (Health Literacy Survey in Europe) scale with 47 items was developed by Sorensen in 2013 (19) and then revised and simplified by Toçi, Bruzari (20) and Sorenson et al. (2013) as Health Literacy Scale (HLS). Its validity and reliability 
in Turkey was performed by Aras and Temel in 2017 (19-21). $\mathrm{HLS}$ is comprised of 25 items and 4 sub-scales. Access to Information includes five items (items 1 to 5 ), and the minimum and maximum scores to be received from this sub-scale are 5 and 25 , respectively. Understanding Information has seven items (items through 6 and 12), and the minimum and maximum scores to be received from this sub-scale are 7 and 35 , respectively. Valuation/Evaluation sub-scale includes eight items (items 13 to 20), and the minimum and maximum scores to be received from this sub-scale are 8 and 40 , respectively. Implementation/Utilization sub-scale has five items (items through 21 to 25), and the minimum and maximum scores to be received from this sub-scale are 5 and 25, respectively. Minimum and maximum scores for the whole scale are 25 and 125 , respectively. This Likert-type scale is responded by the participants as " $5:$ I have no difficulty, 4: I have slight difficulty, 3: I have some difficulty, 2: I have a lot of difficulty, 1: I am not capable/l have no capacity/impossible. All items of the scale have a positive nature, there are no reverse items. Time needed for the completion of the scale is 5-10 minutes. Low scores show that health literacy is insufficient, problematic and weak; high scores demonstrate sufficient and very good health literacy. The higher the score is, the higher the health literacy of the participant is. Cronbach Alpha coefficient of the scale was found as 0.92 in the validity study (21).

In this study, the Cronbach Alpha value of the scale was found as 0.93 , and sub-scale Cronbach Alpha value was detected between the range of $0.75-0.87$.

\section{Data Collection}

Data were collected from the mothers of child patients aged 0-5 years presenting to Çukurova University, Balcalı Hospital, Pediatric Health and Pediatric Infectious Diseases Polyclinics. Face-to-face interview technique was used in data collection, and it took approximately 15 minutes to collect the data.

\section{Data Analysis}

For the evaluation of research findings, IBM SPSS Statistics 20 (IBM SPSS, Turkey) program was used for statistical analyses. In the evaluation of data, apart from descriptive statistical methods (mean, standard deviation, frequency, min-max), Independent Sample $t$ test was used for the comparisons between two groups, Kruskal Wallis $\mathrm{H}$ test and One-Way ANOVA test were used for comparisons between more than two groups, and post hoc test and dual comparisons in Kruskal Wallis $\mathrm{H}$ test were used to detect the group causing the difference. $p<0.05$ was accepted as statistically significant.

\section{Ethics Aspect of the Research}

Approval was obtained from the Ethics Board of Çukurova University, Faculty of Medicine (2019/93/23), and Academic Board approval was also received from the Department of Pediatrics. Written and oral informed consent was also obtained from the parents participating in the research by explaining its objective.

\section{Results}

Mean age of the mothers participating in the study was $30.20 \pm 5.89$ years. Forty-six point four percent of them were primary school and secondary school graduates, $53.6 \%$ had a bad perception of income, $95.9 \%$ stated that vaccines were necessary, $4.1 \%$ indicated that getting vaccinated was not necessary or that they were irresolute about the issue. The reason for being irresolute or against vaccination was that $3.2 \%$ of the mothers believed that vaccines contained harmful substances and did not trust vaccine companies. Table 1 and Table 2 summarizes other sociodemographic and vaccine-related information of the parents.

Mean total score of HLS in this research was $106.80 \pm 17.44$. Moreover, mean score of the "Access to Information" sub-scale was $21.08 \pm 4.54$, that of "Comprehending Information" was "29.08 \pm 5.54 , that of "Valuation/Evaluation" was $39.32 \pm 6.62$, and that of "Implementation/Utilization" was $17.30 \pm 3.15$.

When findings related to the comparison of mean total HLS score according to some personal characteristics of the mothers, a significant difference was determined between mean HLS scores in terms of the education status of the mothers $(p<0.001)$. As a result of the further analysis conducted, the difference was determined to have been caused by the illiterate group $(p<0.005)$ (Table 4).

Significant difference was detected between mean total HLS scores of the mothers in terms of the mothers' perception of income $(p<0.001)$. As a result of the further analysis conducted, the difference was determined to have been caused by the group with bad income status $(p<0.001)$ (Table 4$)$.

Significant difference was detected between mean total HLS scores of the mothers in terms of their employment status and social security status $(p=0.005 ; p<0.001)$. Mean total HLS score of working mothers with social security was detected higher $(p<0.001)$ (Table 4).

Significant difference was detected between mean total HLS scores of the mothers in terms of the number of children $(p<0.001)$. As a result of the further analysis conducted, the difference was found to have resulted from the group with threeor more children $(p<0.001)$ (Table 4).

When the results related to the comparison of mean HLS scores of the mothers according to their knowledge and attitude towards vaccines are evaluated, a significant difference was not detected between the total HLS scores of the mothers in terms of the necessity of getting vaccinated $(p=0.933)$ (Table 5).

A significant difference was detected between the mothers' total HLS scores and the condition of getting their children 
Table 1. Mothers' sociodemographic characteristics

\begin{tabular}{|c|c|c|}
\hline Characteristics & $X \pm S s$ & Min-Max \\
\hline \multirow[t]{2}{*}{$\begin{array}{l}\text { Mean age of the child (month) } \\
\text { Mean age of the mother (year) } \\
\text { Mean age of the father (year) } \\
\text { Mean number of children }\end{array}$} & $\begin{array}{c}25.70 \pm 18.74 \\
30.20 \pm 5.89 \\
34.15 \pm 6.14 \\
2.58 \pm 1.39\end{array}$ & $\begin{array}{c}1-60 \\
19-55 \\
20-55 \\
1-11\end{array}$ \\
\hline & Number & $\%$ \\
\hline $\begin{array}{l}\text { Mother's age } \\
25 \text { years and under } \\
25 \text { years and over }\end{array}$ & $\begin{array}{c}55 \\
164\end{array}$ & $\begin{array}{l}25.0 \\
74.5\end{array}$ \\
\hline $\begin{array}{l}\text { Mother's education level } \\
\text { Illiterate } \\
\text { Primary/secondary school } \\
\text { High school } \\
\text { University }\end{array}$ & $\begin{array}{c}27 \\
102 \\
58 \\
33 \\
\end{array}$ & $\begin{array}{l}12.2 \\
46.4 \\
26.4 \\
15.0\end{array}$ \\
\hline $\begin{array}{l}\text { Mother's employment status } \\
\text { Employed } \\
\text { Unemployed }\end{array}$ & $\begin{array}{c}25 \\
195 \\
\end{array}$ & $\begin{array}{l}11.4 \\
88.6\end{array}$ \\
\hline $\begin{array}{l}\text { Perception of income } \\
\text { Good } \\
\text { Fair } \\
\text { Bad }\end{array}$ & $\begin{array}{c}96 \\
6 \\
118 \\
\end{array}$ & $\begin{array}{c}43.6 \\
2.7 \\
53.6 \\
\end{array}$ \\
\hline $\begin{array}{l}\text { Social security status } \\
\text { Existing } \\
\text { None }\end{array}$ & $\begin{array}{c}165 \\
54 \\
\end{array}$ & $\begin{array}{l}75.0 \\
24.5 \\
\end{array}$ \\
\hline $\begin{array}{l}\text { Place of Inhabit } \\
\text { Province } \\
\text { County }\end{array}$ & $\begin{array}{c}173 \\
47 \\
\end{array}$ & $\begin{array}{l}78.6 \\
21.4 \\
\end{array}$ \\
\hline $\begin{array}{l}\text { Number of children } \\
\text { Single child } \\
1-2 \\
3 \text { and more }\end{array}$ & $\begin{array}{c}47 \\
132 \\
41\end{array}$ & $\begin{array}{l}21.4 \\
60.0 \\
18.6\end{array}$ \\
\hline
\end{tabular}

immunized with paid vaccinations. Mean total HLS scores of the mothers getting their children immunized with paid vaccinations was found higher $(p=0.004)$ (Table 5).

Significant difference was detected the mothers' total HLS scores and the reason of not getting their children immunized with paid vaccinations. As a result of the further analysis conducted, the difference was found to have been caused by the group with no financial opportunity $(p=0.004)$ (Table 5).

A significant difference was detected between the mothers' total HLS scores and the condition of getting their children immunized with paid vaccinations. Mean total HLS scores of the mothers getting their children immunized with pay vaccines was found higher $(p=0.004)$ (Table 5).

\section{Discussion}

In this study conducted to determine the association between $\mathrm{HL}$ and childhood vaccine acceptance or refusal of mothers with children aged 0-5 years, it was determined that a majority of the mothers accepted the vaccines and HL levels of the mothers were sufficient.
Immunization is one of the most effective means of public health to prevent and eradicate infectious diseases, to diminish deaths and to improve health (22). In this study, 95.9\% of the mothers indicated that vaccines are necessary. In studies by Özceylan et al. (2020) (5) and by Ertuğrul (2019) (23), 89.3\% of the mothers and $95.3 \%$ of the parents have been reported to have stated that vaccination was necessary, respectively. Veldwijk et al. (2015) have reported that $90 \%$ of the parents considered getting their newborn children vaccinated (12). Our study results are parallel to other research results showing that the importance given to vaccines is high, and we put forward that parent sensitivity towards getting their children vaccinated was at a satisfying level.

In our study, $97.7 \%$ of the mothers were detected to have knowledge on vaccines, $82.7 \%$ of whom obtained information from nurses/midwives/health staff and $46.4 \%$ of whom obtained information from physicians. $80.1 \%$ of the parents in the study by Soyer et al. (2011) (24) and $61.1 \%$ of the mothers in the study by Arlı (2018) (17) have stated that they obtained information on vaccines from physicians. 
Table 2. Mothers' characteristics related to their knowledge and attitude towards vaccines

\begin{tabular}{|c|c|c|}
\hline Characteristics & Number & $\%$ \\
\hline $\begin{array}{l}\text { Do you have knowledge on vaccines? } \\
\text { Yes } \\
\text { No }\end{array}$ & $\begin{array}{c}215 \\
5 \\
\end{array}$ & $\begin{array}{c}97.7 \\
2.3 \\
\end{array}$ \\
\hline $\begin{array}{l}\text { Do you think vaccines are necessary? } \\
\text { Yes } \\
\text { No } \\
\text { Neutral }\end{array}$ & $\begin{array}{c}211 \\
2 \\
7\end{array}$ & $\begin{array}{c}95.9 \\
0.9 \\
3.2\end{array}$ \\
\hline $\begin{array}{l}\text { What is the reason if vaccines are not necessary? }(n=9) \\
\text { I believe they contain harmful substances and I do not trust vaccine companies } \\
\text { I have heard on tv and the internet that they are harmful } \\
\text { I do not trust healthcare workers }\end{array}$ & $\begin{array}{l}7 \\
1 \\
1\end{array}$ & $\begin{array}{l}3.2 \\
0.5 \\
0.5\end{array}$ \\
\hline $\begin{array}{l}\text { From where or whom did you get the information? }(n=215) \\
\text { Nurse/midwife/health staff } \\
\text { Physician } \\
\text { Tv-radio-newspaper-internet } \\
\text { Neighbours/relatives }\end{array}$ & $\begin{array}{l}182 \\
102 \\
77 \\
34\end{array}$ & $\begin{array}{l}82.7 \\
46.4 \\
35.0 \\
15.5\end{array}$ \\
\hline $\begin{array}{l}\text { Knowledge on vaccines }(n=213) \\
\text { Protects from diseases } \\
\text { Provides immunity against microbes } \\
\text { To be healthy } \\
\text { I do not know }\end{array}$ & $\begin{array}{c}198 \\
182 \\
176 \\
7\end{array}$ & $\begin{array}{c}90 \\
82.7 \\
80 \\
3.2\end{array}$ \\
\hline $\begin{array}{l}\text { How bad is it if your child does not get vaccinated? }(n=213) \\
\text { Infection risk increases } \\
\text { Suffers from infectious diseases } \\
\text { Gets sick quickly } \\
\text { Gets sick more frequently } \\
\text { Suffers from diseases severely } \\
\text { Can catch lethal infectious diseases } \\
\text { Can have a disability following the infectious disease } \\
\text { I do not know }\end{array}$ & $\begin{array}{c}177 \\
188 \\
180 \\
176 \\
177 \\
150 \\
134 \\
7 \\
\end{array}$ & $\begin{array}{c}80.5 \\
85.5 \\
81.8 \\
80.0 \\
80.5 \\
68.2 \\
60.9 \\
3.2 \\
\end{array}$ \\
\hline $\begin{array}{l}\text { Do vaccines have side effects? } \\
\text { Yes } \\
\text { No } \\
\text { I do not know }\end{array}$ & $\begin{array}{l}139 \\
48 \\
33\end{array}$ & $\begin{array}{l}63.2 \\
21.8 \\
15.0\end{array}$ \\
\hline $\begin{array}{l}\text { What are the side effects of vaccines? }(n=187) \\
\text { Fever } \\
\text { Infection } \\
\text { Allergy } \\
\text { Stroke } \\
\text { Pain }\end{array}$ & $\begin{array}{l}135 \\
47 \\
75 \\
41 \\
83\end{array}$ & $\begin{array}{l}61.4 \\
21.4 \\
34.1 \\
18.6 \\
37.7\end{array}$ \\
\hline $\begin{array}{l}\text { What are the childhood vaccines that you know of? }(n=162) \\
\text { Measles } \\
\text { Hepatitis B } \\
\text { Tuberculosis } \\
\text { Varicella } \\
\text { Tetanus } \\
\text { Polio }\end{array}$ & $\begin{array}{l}94 \\
86 \\
64 \\
45 \\
39 \\
29\end{array}$ & $\begin{array}{l}42.7 \\
39.1 \\
29.1 \\
20.5 \\
17.7 \\
13.2\end{array}$ \\
\hline $\begin{array}{l}\text { Are you informed about paid vaccinations? } \\
\text { Yes } \\
\text { No }\end{array}$ & $\begin{array}{l}110 \\
110 \\
\end{array}$ & $\begin{array}{l}50 \\
50\end{array}$ \\
\hline $\begin{array}{l}\text { Have you got your child vaccinated with paid vaccinations? } \\
\text { Yes } \\
\text { No }\end{array}$ & $\begin{array}{c}16 \\
204\end{array}$ & $\begin{array}{c}7.3 \\
92.7\end{array}$ \\
\hline
\end{tabular}


Table 2. Mothers' characteristics related to their knowledge and attitude towards vaccines (continue)

\begin{tabular}{|c|c|c|}
\hline Characteristics & Number & $\%$ \\
\hline $\begin{array}{l}\text { What is the reason for not getting paid vaccinations? }(n=204) \\
\text { I have no information on the matter } \\
\text { I have no financial possibilities } \\
\text { I do not think they are necessary }\end{array}$ & $\begin{array}{c}110 \\
53 \\
41\end{array}$ & $\begin{array}{c}50 \\
24.1 \\
18.6\end{array}$ \\
\hline $\begin{array}{l}\text { Under what circumstances are vaccines postponed? } \\
\text { Infection } \\
\text { High fever } \\
\text { There are no obstacles } \\
\text { I do not know }\end{array}$ & $\begin{array}{l}145 \\
157 \\
8 \\
29\end{array}$ & $\begin{array}{c}65.9 \\
71.4 \\
3.6 \\
13.2\end{array}$ \\
\hline
\end{tabular}

Table 3. Mothers' mean HL scores

\begin{tabular}{|l|c|c|c|}
\hline Sub-scales & $\mathbf{X} \pm$ Ss & Min-max & Cronbach Alfa \\
\hline Access to information & $21.08 \pm 4.54$ & $5-25$ & 0.856 \\
\hline Comprehending information & $29.08 \pm 5.54$ & $7-35$ & 0.788 \\
\hline Valuation/Evaluation & $39.32 \pm 6.62$ & $12-45$ & 0.870 \\
\hline Implementation/Utilization & $17.30 \pm 3.15$ & $4-20$ & 0.757 \\
\hline Total & $106.80 \pm 17.44$ & $29-125$ & 0.935 \\
\hline
\end{tabular}

Table 4. Comparison of mothers' mean HLS scores according to some informative characteristics

\begin{tabular}{|c|c|c|c|c|c|}
\hline & $\begin{array}{l}\text { Access to } \\
\text { Information } \\
X \pm S s\end{array}$ & $\begin{array}{l}\text { Comprehending } \\
\text { Information } \\
\mathrm{X} \pm \mathrm{Ss}\end{array}$ & $\begin{array}{c}\text { Valuation/Evaluation } \\
\mathrm{X}+\mathrm{Ss}\end{array}$ & $\begin{array}{l}\text { Implementation/ } \\
\text { Utilization } X+S s\end{array}$ & $\begin{array}{c}\mathrm{HL} \\
\mathrm{X}+\mathrm{Ss}\end{array}$ \\
\hline $\begin{array}{l}\text { Mothers' education level } \\
\text { Illiterate } \\
\text { Primary/Secondary school } \\
\text { High school } \\
\text { University }\end{array}$ & $\begin{array}{l}16.33 \pm 6.1 \\
20.71 \pm 4.4 \\
22.58 \pm 2.8 \\
23.45 \pm 2.3 \\
\mathbf{F}=\mathbf{1 8 . 8 2 7} \\
\mathbf{p}=\mathbf{0} .000^{* *}\end{array}$ & $\begin{array}{l}22.18 \pm 7.4 \\
29.22 \pm 4.9 \\
30.31 \pm 3.7 \\
32.15 \pm 3.1 \\
\mathbf{F}=\mathbf{2 4 . 0 0 9} \\
\mathbf{p}=\mathbf{0 . 0 0 0 * *}\end{array}$ & $\begin{array}{c}34.29 \pm 9.0 \\
39.20 \pm 6.6 \\
40.44 \pm 5.1 \\
41.81 \pm 4.0 \\
F=8.003 \\
\mathbf{p}=\mathbf{0 . 0 0 0 * *}\end{array}$ & $\begin{array}{c}15.77 \pm 3.7 \\
17.01 \pm 3.4 \\
17.75 \pm 2.3 \\
18.66 \pm 1.8 \\
\mathbf{F}=\mathbf{5 . 1 1 0} \\
\mathbf{p}=\mathbf{0 . 0 0 2 *}\end{array}$ & $\begin{array}{c}88.59 \pm 24.0 \\
106.16 \pm 16.7 \\
111.10 \pm 11.3 \\
116.09 \pm 9.6 \\
\mathbf{F}=\mathbf{1 7 . 3 1 2} \\
\mathbf{p}=\mathbf{0 . 0 0 0 * *}\end{array}$ \\
\hline $\begin{array}{l}\text { Perception of income } \\
\text { Bad } \\
\text { Fair } \\
\text { Good }\end{array}$ & $\begin{array}{l}19.64 \pm 5.2 \\
23.16 \pm 2.7 \\
22.71 \pm 2.8 \\
\mathbf{X}^{2}=\mathbf{2 4 . 2 2 8} \\
\mathbf{p}=\mathbf{0 . 0 0 0 * *}\end{array}$ & $\begin{array}{c}27.72 \pm 6.3 \\
30.66 \pm 4.5 \\
30.66 \pm 3.9 \\
\mathbf{X}^{2}=\mathbf{1 1 . 8 0 9} \\
\mathbf{p}=\mathbf{0 . 0 0 3 *}\end{array}$ & $\begin{array}{l}37.78 \pm 7.8 \\
41.16 \pm 5.4 \\
41.09 \pm 4.2 \\
\mathbf{X}^{2}=\mathbf{9 . 9 1 9} \\
\mathbf{p}=\mathbf{0 . 0 0 7 *}\end{array}$ & $\begin{array}{l}16.67 \pm 3.6 \\
17.66 \pm 2.7 \\
18.06 \pm 2.2 \\
\mathbf{X}^{2}=\mathbf{7 . 6 0 3} \\
\mathbf{p}=\mathbf{0 . 0 2 2 *}\end{array}$ & $\begin{array}{l}101.83 \pm 20.3 \\
112.66 \pm 13.0 \\
112.54 \pm 10.7 \\
\mathbf{X}^{2}=\mathbf{1 7 . 6 4 3} \\
\mathbf{p}=\mathbf{0 . 0 0 0 * *}\end{array}$ \\
\hline $\begin{array}{l}\text { Mothers'employment status } \\
\text { Employed } \\
\text { Unemployed }\end{array}$ & $\begin{array}{c}23.92 \pm 2.4 \\
20.71 \pm 4.6 \\
\mathbf{t}=\mathbf{- 5 . 3 8 9} \\
\mathbf{p}=\mathbf{0 . 0 0 0 * *}\end{array}$ & $\begin{array}{l}32.20 \pm 3.8 \\
28.68 \pm 5.6 \\
\mathbf{t}=-\mathbf{3 . 0 3 7} \\
\mathbf{p}=\mathbf{0 . 0 5 4}\end{array}$ & $\begin{array}{c}43.24 \pm 2.3 \\
38.82 \pm 6.8 \\
\mathbf{t}=-\mathbf{6 . 5 3 7} \\
\mathbf{p}=\mathbf{0 . 0 0 0 * *}\end{array}$ & $\begin{array}{l}18.84 \pm 1.9 \\
17.11 \pm 3.2 \\
\mathbf{t}=\mathbf{- 3 . 8 0 8} \\
\mathbf{p}=\mathbf{0 . 0 1 6 ^ { * }}\end{array}$ & $\begin{array}{c}118.20 \pm 8.5 \\
105.33 \pm 17.7 \\
\mathbf{t}=-\mathbf{6 . 0 4 0} \\
\mathbf{p}=\mathbf{0 . 0 0 5 *}\end{array}$ \\
\hline $\begin{array}{l}\text { Social security status } \\
\text { Existing } \\
\text { None }\end{array}$ & $\begin{array}{c}22.03 \pm 3.5 \\
18.09 \pm 5.8 \\
\mathbf{t}=\mathbf{4 . 6 5 0} \\
\mathbf{p}=\mathbf{0 . 0 0 0 * *}\end{array}$ & $\begin{array}{c}29.96 \pm 4.2 \\
26.31 \pm 7.7 \\
t=3.304 \\
p=0.000^{* *}\end{array}$ & $\begin{array}{c}40.50 \pm 4.8 \\
35.62 \pm 9.4 \\
\mathbf{t}=\mathbf{3 . 6 2 8} \\
\mathbf{p}=\mathbf{0 . 0 0 0 * *}\end{array}$ & $\begin{array}{c}17.78 \pm 2.5 \\
15.81 \pm 4.2 \\
\mathbf{t}=\mathbf{3 . 2 2 3} \\
\mathbf{p}=\mathbf{0 . 0 0 0 * *}\end{array}$ & $\begin{array}{c}110.29 \pm 12.4 \\
95.85 \pm 24.8 \\
\mathbf{t}=\mathbf{4 . 1 0 8} \\
\mathbf{p}=\mathbf{0 . 0 0 0 *}\end{array}$ \\
\hline $\begin{array}{l}\text { Number of children } \\
\text { Singe childe } \\
1-2 \\
3 \text { and more }\end{array}$ & $\begin{array}{l}21.97 \pm 3.7 \\
21.71 \pm 3.9 \\
18.00 \pm 5.7 \\
\mathbf{F}=\mathbf{1 2 . 8 7 9} \\
\mathbf{p}=\mathbf{0 . 0 0 0 * *}\end{array}$ & $\begin{array}{c}30.04 \pm 4.2 \\
29.61 \pm 5.1 \\
26.29 \pm 7.0 \\
F=\mathbf{6 . 8 4 2} \\
\mathbf{p}=\mathbf{0 . 0 0 1 *}\end{array}$ & $\begin{array}{l}40.02 \pm 5.6 \\
40.08 \pm 5.8 \\
36.07 \pm 8.8 \\
\mathbf{F}=\mathbf{6 . 3 5 3} \\
\mathbf{p}=\mathbf{0 . 0 0 2}\end{array}$ & $\begin{array}{c}18.12 \pm 2.2 \\
17.56 \pm 2.8 \\
15.56 \pm 4.1 \\
\mathrm{~F}=\mathbf{8 . 8 9 7} \\
\mathbf{p}=\mathbf{0 . 0 0 0 * *}\end{array}$ & $\begin{array}{c}110.17 \pm 12.8 \\
108.97 \pm 15.4 \\
95.92 \pm 23.2 \\
F=10.752 \\
\mathbf{p}=\mathbf{0} .000 * *\end{array}$ \\
\hline \multicolumn{6}{|c|}{$\begin{array}{l}\text { t: Independent Sample } t \text { test, F: One-Way ANOVA, } X^{2} \text { : Kruskal Wallis H test. } \\
{ }^{*} p<0.05 \\
{ }^{* *} p<0.001\end{array}$} \\
\hline
\end{tabular}


Yıldızeli et al.

Table 5. Comparison of mothers' mean HLS score according to their knowledge and attitue towards vaccines

\begin{tabular}{|c|c|c|c|c|c|}
\hline & $\begin{array}{c}\text { Access to } \\
\text { Information } \\
\mathrm{X} \pm \mathrm{SS}\end{array}$ & $\begin{array}{l}\text { Comprehending } \\
\text { Information } \\
\mathrm{X} \pm \mathrm{SS}\end{array}$ & $\begin{array}{l}\text { Valuation/ } \\
\text { Evaluation } \\
\quad \mathrm{X} \pm \mathrm{SS}\end{array}$ & $\begin{array}{l}\text { Implementation/ } \\
\text { Utilization } \mathrm{X} \pm \mathrm{SS}\end{array}$ & $\begin{array}{c}\mathrm{HL} \\
\mathrm{X} \pm \mathrm{SS}\end{array}$ \\
\hline $\begin{array}{l}\text { Do you think vaccines are necessary? } \\
\text { Yes } \\
\text { No } \\
\text { Neutral }\end{array}$ & $\begin{array}{l}21.11 \pm 4.5 \\
21.00 \pm 4.2 \\
20.14 \pm 4.9 \\
\mathbf{X}^{2}=\mathbf{0 . 4 9 7} \\
\mathbf{p}=\mathbf{0 . 7 8 0}\end{array}$ & $\begin{array}{c}29.06 \pm 5.5 \\
30.00 \pm 1.4 \\
29.42 \pm 5.0 \\
\mathbf{X}^{2}=\mathbf{0 . 0 4 5} \\
\mathbf{p}=\mathbf{0 . 9 7 8}\end{array}$ & $\begin{array}{c}39.34 \pm 6.6 \\
40.00 \pm 0.0 \\
38.57 \pm 6.9 \\
\mathbf{X}^{2}=\mathbf{0} . \mathbf{2 3 7} \\
\mathbf{p}=\mathbf{0 . 8 8 8}\end{array}$ & $\begin{array}{c}17.29 \pm 3.1 \\
18.50 \pm 2.1 \\
17.42 \pm 2.2 \\
\mathbf{X}^{2}=\mathbf{0 . 3 2 2} \\
\mathbf{p}=\mathbf{0 . 8 5 1}\end{array}$ & $\begin{array}{c}106.8 \pm 17.5 \\
109.50 \pm 7.7 \\
105.57 \pm 17.2 \\
\mathbf{X}^{2}=\mathbf{0 . 1 3 8} \\
\mathbf{p}=\mathbf{0 . 9 3 3}\end{array}$ \\
\hline $\begin{array}{l}\text { Have you got your child vaccinated with paid vaccinations? } \\
\text { Yes } \\
\text { No }\end{array}$ & $\begin{array}{c}23.50 \pm 2.5 \\
20.51 \pm 4.7 \\
\mathbf{t}=\mathbf{5 . 6 5 4} \\
\mathbf{p}=\mathbf{0 . 0 0 0 * *}\end{array}$ & $\begin{array}{c}31.83 \pm 3.2 \\
28.43 \pm 5.7 \\
\mathbf{t}=\mathbf{5 . 1 0 2} \\
\mathbf{p}=\mathbf{0 . 0 0 2 *}\end{array}$ & $\begin{array}{c}41.78 \pm 4.4 \\
38.74 \pm 6.9 \\
t=3.529 \\
p=0.010^{*}\end{array}$ & $\begin{array}{c}18.23 \pm 2.0 \\
17.08 \pm 3.3 \\
\mathbf{t}=\mathbf{2 . 8 3 4} \\
\mathbf{p}=\mathbf{0 . 0 1 6}\end{array}$ & $\begin{array}{c}115.35 \pm 10.0 \\
104.78 \pm 18.2 \\
\mathbf{t}=\mathbf{5 . 1 0 7} \\
\mathbf{p}=\mathbf{0 . 0 0 4}\end{array}$ \\
\hline $\begin{array}{l}\text { The reasons for not getting paid vaccinations }(n=178) \\
\text { No information } \\
\text { No financial possibility } \\
\text { Do not think they are necessary }\end{array}$ & $\begin{array}{c}20.58 \pm 4.9 \\
10.94 \pm 4.6 \\
23.09 \pm 2.5 \\
\mathbf{F}=\mathbf{6 . 4 2 4} \\
\mathbf{p}=\mathbf{0 . 0 0 2 *}\end{array}$ & $\begin{array}{c}28.14 \pm 6.1 \\
28.86 \pm 5.4 \\
30.73 \pm 3.6 \\
\mathbf{F}=\mathbf{3 . 1 9 0} \\
\mathbf{p}=\mathbf{0 . 0 4 3}\end{array}$ & $\begin{array}{c}38.60 \pm 7.0 \\
38.13 \pm 7.3 \\
42.00 \pm 3.2 \\
F=\mathbf{4 . 8 6 0} \\
\mathbf{p}=\mathbf{0 . 0 0 9 *}\end{array}$ & $\begin{array}{c}17.06 \pm 3.2 \\
16.71 \pm 3.7 \\
18.43 \pm 2.0 \\
\mathbf{F}=\mathbf{3 . 7 7 2} \\
\mathbf{p}=\mathbf{0 . 0 2 5}\end{array}$ & $\begin{array}{c}104.39 \pm 19.1 \\
103.66 \pm 18.3 \\
114.26 \pm 9.1 \\
\mathbf{F}=\mathbf{5 . 5 9 3} \\
\mathbf{p}=\mathbf{0} . \mathbf{0 0 4}\end{array}$ \\
\hline \multicolumn{6}{|l|}{$\begin{array}{l}\text { t: Independent Sample } t \text { test, } F: \text { One-Way ANOVA, } X \text { : Kruskal Wallis } H \text { test. } \\
{ }^{*} p<0.05 . \\
{ }^{* *} p<0.001 .\end{array}$} \\
\hline
\end{tabular}

In our study, $4.1 \%$ of the mothers expressed that they were irresolute and getting their children vaccinated was not necessary, and $3.2 \%$ of these mothers stated that their hesitation was due to the fact that vaccines contained harmful substances and they did not believe in vaccine companies. The study by Yazıcı (2018) (1) has detected that 39\% of the parents did not trust the content of vaccines. In the studies by Özceylan et al. (2020) (5) and Bozkurt'un (2018) (25), the most common cause of vaccine hesitation has been found as lack of confidence in vaccine companies. Ertuğrul's study (2019) has pointed out that $4.7 \%$ of the parents thought that getting their children vaccinated was not necessary and that they did not trust the vaccines $(2.5 \%)$ and were afraid of the side effects of the vaccines (2.2\%) (23). The reason for the low rate of hesitant mothers or mothers who do not want their children to get the vaccines is believed to be the result of a performance system implemented by the state in the follow-up of childhood vaccinations, and thus vaccine-related policies in the state's preventive health service are strong and healthcare workers exhibit a highly positive effort.

In this research, mothers' health literacy levels were determined to be sufficient. According to the results of a study conducted by the Directorate General of Health Improvement of the Ministry of Health to identify health literacy levels in Turkey and related factors (2019), 7\%, 23.4\%, 38\%, and 39.9\% of the participants have been reported to have perfect, sufficient, problematic-limited, and insufficient HL levels, respectively (26). In other studies, it has been reported that HL levels in Turkey ranged between $32.5 \%$ and $35.4 \%$ (27-29).
In studies conducted abroad, $\mathrm{HL}$ levels have been reported sufficient $(12-14,30)$. According to a large-scale research conducted to determine HL in Europe by Sorenson et al. (2015), it has been reported that $\mathrm{HL}$ levels in some countries such as the Netherlands, Germany, Poland, and Ireland were above average, and while the highest $\mathrm{HL}$ levels were found in the Netherlands (72\%) and Ireland (60\%), the lowest levels were found in Bulgaria (37\%) and Spain (42\%) (31).

According to a research from our country, it is seen that our HL level, when compared to that of Europe, is below average $(23,26-29)$. This study, which we conducted in a university hospital, reached different results compared to the studies conducted country-wide since our results showed that $95.9 \%$ considered vaccines necessary and HL levels were sufficient.

In this study, it was seen that the higher the education status of the mothers was, the higher their HL levels was. $\mathrm{HL}$ levels of illiterate mothers were detected the lowest. In studies conducted, it has been determined that as the mothers' education level increased, so did their HL levels $(18,28,29,32,33)$. However, in the literature, there are studies detecting low $\mathrm{HL}$ levels in individuals with high education levels $(12,13,34)$ or studies showing no significant relation between education level and HL level $(14,23,28)$. The fact that education affects the level of health literacy is an important result. Education plays a vital role in this positive result since it develops learning skills and eases comprehension, in general.

In this study, mothers with bad income were found to have low HL levels. In studies conducted on the matter, along with 
studies suggesting that $\mathrm{HL}$ levels also increase with the increase in income levels (35-37), there is also a study that has found low HL despite high income levels (38). In addition, a significant difference could not have been found between monthly income of families and their HL levels $(12,13,23,28,30,35,36)$. Along with various results in the literature, it is possible to state that $\mathrm{HL}$ levels are positively affected by the increase in public welfare and the ease in reaching healthcare services in parallel to the income status.

In this research, $\mathrm{HL}$ levels of mothers who were employed and had social security were found higher. Being employed means that the mothers have social security. In studies by Şen Uğur (2016) (37), Özdemir (2018) (39), and Öncü et al. (2018) (40), HL levels of the individuals who were employed and had social security were determined higher. In other studies, it has been indicated that $\mathrm{HL}$ levels did not change according to employment status $(35,39)$. Along with different results in the literature, it can be said that an increase in HL levels is an expected result of high socioeconomic conditions.

In our study, HL levels of the mothers who got their children immunized with paid vaccinations were found higher compared to mothers who did not. Moreover, it was also found that the reason for not getting paid vaccinations was significantly related to $\mathrm{HL}$ levels, and mothers with insufficient financial opportunities had lower HL levels. Arlı's study (2018) (17) has emphasized that $78.3 \%$ of the parents got their children immunized with paid vaccinations, $21.7 \%$ did not and the reason for not getting their children immunized with paid vaccinations was that $62.2 \%$ did not have information on paid vaccinations and $10.6 \%$ did not have the financial opportunity.

Our study pointed out that $\mathrm{HL}$ levels decreased with the increase in the number of children. In the study of Ulusoy (2019) (28) a negative relation has been reported between the number of children and HL levels, similar to our study. Brandstetter et al. (2020) have determined that HL level was lower in mothers with first child and low education level (30).

\section{Conclusion}

This research concluded that a majority of the mothers considered vaccinations necessary and had a sufficient HL level. Moreover, mothers' HL levels were found to have been affected by their education level, income status, their employment status, their social security status, the number of children, the condition of getting paid vaccinations, the reasons of not getting paid vaccinations.

The importance of the notion of $\mathrm{HL}$ is getting more prominent day by day. All healthcare professionals that have a vital role in the protection, continuation and improvement of health and also nurses who actively execute their role as health instructors and consultants, independent of their duties, inform parents on the importance of childhood vaccines and continue educating parents on the matter, which, in turn, provide more conscious and efficient healthcare applications and serve as a significant tool in improving public health. In addition, it is recommended to conduct larger scale studies with a wider population and sample.

\section{Limitations of the Research}

Since this study was conducted in a hospital, it gives information related to a small sample group. Therefore, it is not possible to generalize the study results to the whole public. Hence, larger-scale studies are needed at the nation level.

Ethics Committe Approval: The approval for this study was obtained from Çukurova University Faculty of Medicine Non-Invasive Clinical Research Ethics Committee (Decision No: 23, Date: 01.11.2019). Informed Consent: Patient consent was obtained.

Peer-review: Externally peer-reviewed.

Author Contributions: Concept - DA, FY, EG; Design - DA, FY; Supervision - DA, FY, EG; Resource - FY; Data Collection and/or Processing - FY, EG; Analysis and/or Interpretation - FY, EG; Literature Search - FY, EG; Writing - FY, EG; Critical Review - DA, EG.

Conflict of Interest: All authors declare that they have no conflicts of interest or funding to disclose.

Financial Disclosure: The authors declared that this study has received no financial support.

\section{References}

1. Yazıcı E. Çocukluk Çağı Aşıları Ille IIlgili Ebeveynlerin Bilgi ve Tutumları. Aile Hekimliği Uzmanlık Tezi. 2018. Sağlık Bilimleri Üniversitesi, Ankara. [CrossRef]

2. Sağlığa Aşılanın, 2018. T.C. Sağlık Bakanlığı. Available from: https:// www.saglik.gov.tr/TR,21088/sagliga-asilanin.html (Accessed date: 6 October 2019). [CrossRef]

3. WHO, UNICEF. World Bank State of the World's Vaccines and Immunization, $3^{\text {rd }}$ ed. Geneva, WHO 2009. [CrossRef]

4. T.C. Sağlık Bakanlığı, Sağlık Istatistikleri Yıllığı 2017 Haber Bülteni, 2017. Available from: https://dosyamerkez.saglik.gov.tr/ (Accessed date: 11 March 2020). [CrossRef]

5. Özceylan G, Toprak D, Esen ES. Vaccine rejection and hesitation in Turkey. Hum Vaccin Immunother 2020;6:1-6. [CrossRef]

6. Sorensen K, Van den Broucke S, Fullam J, Doyle G, Pelikan J, Slonska Z, Brand H. (HLS-EU) Consortium Health Literacy Project European. Health literacy and public health: a systematic review and integration of definitions and models. BMC Public Health 2012; 25:12-80. [CrossRef]

7. Lorinia C, Santomauroa F, Donzellinib M, Capecchib L, Bechini A, Boccalini S, Bonanni P, Bonaccorsia G. Health literacy and vaccination: $A$ systematic review. Human Vaccıne Immunother 2018;14:2:478-88. [CrossRef]

8. Hazır E. 0-24 Aylık Bebek/Çocukların Ebeveynlerinin Aşı Red Sıklığı ve Nedenleri. Yüksek Lisans Tezi. 2018. Okan Üniversitesi Istanbul. [CrossRef] 
Yıldızeli et al.

9. Yüksel GH, Topuzoğlu A. Aşı redlerinin artması ve aşı karşıtlığını etkileyen faktörler. ESTÜDAM Halk Sağlığı Dergisi 2019;4:244-258. [CrossRef]

10. Brown AL, Sperandio M, Turssi CP, Leite RMA, Berton VF, Succi RM, et al. Vaccine confidence and hesitancy in Brazil, Cad. Saúde Pública 2018;34:9:1-12. [CrossRef]

11. Johri M, Subramanian SV, Sylvestre MP, Dudeja S, Chandra D, Kon e GK, et al. Association between maternal health literacy and child vaccination in India: A cross-sectional study. J Epidemiol Community Health 2015;69:849-57. [CrossRef]

12. Veldwijk J, Van der Heide I, Rademakers J, Schuit AJ, de Wit GA, Uiters $E$, et al. Preferences for vaccination: does health literacy make a difference? Med Decis Making 2015;35:8:948-58. [CrossRef]

13. Aharon AA, Nehama H, Rishpon S, Baron-Epel O. Parents with high levels of communicative and critical health literacy are less likely to vaccinate their children. Patient Educ Couns 2017;100:4:768-75. [CrossRef]

14. Pati S, Feemster KA, Mohamad Z, Fiks A, Grundmeier R, Cnaan A. Maternal health literacy and late initiation of immunizations among an inner-city birth cohort. Matern Child Health J 2011;15:386-94. [CrossRef]

15. Gür E. Aşı kararsızlığı - aşı reddi. Turk Pediatri Ars 2019;54:(1):1-2. [CrossRef]

16. Üzüm Ö, Eliaçık K, Hortu Örsdemir H, Karadağ Öncel E. Ebeveynlerin aşı yaklaşımlarını etkileyen faktörler: Bir eğitim araştırma hastanesine ilişkin değerlendirme. J Pediatr Inf 2019;13:3:144-9. [CrossRef]

17. Arlı H. Çocuk Sağlığı Ve Hastalıkları Polk' ne Başvuran 0-24 Ay Aralığında Çocuğu Olan Annelerin Sağlık Bakanlığı Rutin Aşı Takvimi ve Çocuk Aşılaması Hakkında Bilgi Düzeylerinin Değerlendirilmesi. Aile Hekimliği Uzmanlık Tezi, 2018. Sağlık Bilimleri Üniversitesi İzmir Tepecik Sağlık Uygulama ve Araştırma Merkezi, İzmir. [CrossRef]

18. Özdemir IR. Ebeveynlerin Çocukluk Çağı Aşılarına Karşı Bilgi, Tutum ve Davranışları. Yüksek Lisans Tezi, 2017. Marmara Üniversitesi İstanbul. [CrossRef]

19. Sorensen K, Brand H. Health literacy lost in translations? Introducing the European health literacy glossary. Health Promotion International 2013;29:4:634-44. [CrossRef]

20. Toçi E, Burazeri G, Sorensen K, Jerliu N, Ramadani N, Roshi E, et al. Health literacy and socioeconomic characteristics among older people in transitional Kosovo. BJM Med Res 2013;3:4:1646-58. [CrossRef]

21. Aras Z, Temel AB. Sağlık okuryazarlığıölçeği'nin türkçe formunun geçerlik ve güvenirliğinin değerlendirilmesi. FN Hem Dergisi 2017;25:2:85-94. [CrossRef]

22. Fine-Goulden M. Should childhood vaccination be compulsory in the UK? Opticon 2010;1826:8:1-9. [CrossRef]

23. Ertuğrul B. Ebeveynlerin Sağlık Okuryazarlığı Düzeyinin Çocukluk Dönemi Aşılarına Yönelik Tutum ve Davranışlarıyla Iliş̧kisi. Yüksek Lisans Tezi, 2019. Yozgat Bozok Üniversitesi-Kırıkkale Üniversitesi, Yozgat. [CrossRef]

24. Soyer ÖU, Civelek E, Karabulut E, Kocabas C, Şekerel BE. Parental perspectives on influenza vaccination in children with asthma. Pediatr Pulmonol 2011;46:139-44. [CrossRef]

25. Bozkurt HB. Aşı reddine genel bir bakış ve literatürün gözden geçirilmesi. Kafkas J Med Sci 2018;8:1:11-6. [CrossRef]

26. T.C. Sağlık Bakanlığı Sağığın Geliştirilmesi Genel Müdürlüğü, Türkiye'nin Sağlık Okuryazarlığı Düzeyi Ölçüldü. 2019. T.C. Sağlık Bakanlığı Ăg Sitesi. Available from: https://sggm.saglik.gov.tr/TR,57003/turkiyenin-saglik-okuryazarligi-duzeyi-olculdu.html (Accessed date: 11 March 2020). [CrossRef]
27. Tanrı̈̈ver MD, Yıldırım HH, Demiray N, Çakır B, Akalın HE. Türkiye Sağlık Okuryazarlığı Araştırması. Altan Özyurt Matbaacılık. Ankara, 2014. Available from: http://www.sagliksen.org.tr/cdn/uploads/gallery/pdf/8dcec50aa18c21cdaf86a2b33001a409.pdf (Accessed date: 11 March 2020). [CrossRef]

28. Ulusoy E. Aile Sağlığı Merkezine Kayıtı Çocukların Ebeveynlerinin Sağlam Çocuk Takibindeki Sorumlu Sağık Okuryazarlıkları. Uzmanlık Tezi, 2019. Sağlık Bilimleri Üniversitesi, Ankara. [CrossRef]

29. Okyay P, Abacıgil F, Harlak H. Türkiye Sağlık Okuryazarlığı Ölçeği Türkçe-32.Türkiye Sağlık Okuryazarlığı Ölçekleri Güvenilirlik ve Geçerlilik Çalışması. TC Sağlık Bakanlığı. Available from: 2016:43-61. https:// sbu.saglik.gov.tr/Ekutuphane/kitaplar/Sa\%C4\%9FI\%C4\%B1k\%20 Okur\%20Yazarl\%C4\%B1\%C4\%9F\%C4\%B1.pdf (Accessed date: 11 March 2020). [CrossRef]

30. Brandstetter S, AtzendorfJ, Seelbach-Göbel B, Melter M, Kabesch M, Apfelbacher $C$; KUNO-Kids study group. Sociodemographic factors associated with health literacy in a large sample of mothers of newborn children: cross-sectional findings from the KUNO-Kids birth cohort study. Eur J Pediatr 2020;179:(1):165-9. [CrossRef]

31. Sorensen K, Pelikan JM, Röthlin F, Ganahl K, Slonska Z, Doyle G, et al. Brand H Health literacy in Europe: Comparative Results of The European Health Literacy Survey (HLS-EU). Eur J Public Health 2015;25:10538. [CrossRef]

32. Bbaale E. Factors Influencing childhood immunization in Uganda. J Health Popul Nutr 2013;31:(1):118-29. [CrossRef]

33. Sezer A, Kadıoğlu H. Yetişkin sağlık okuryazarlığı ölçeğinin geliştirilmesi. Anadolu Hemşirelik ve Sağlık Bilimleri Dergisi 2014;17:3. [CrossRef]

34. Kohan S, Ghasemi S, Dodangeh M. Associations between maternal health literacy and prenatal care and pregnancy outcome, Iranian J Nursing Midwifwery Res 2007;12:4:146-52. [CrossRef]

35. Duman A. Fatih Illçesinde IIlkokul 1. Sınıf Aşılamalarında Velilerin Genel Sağlık Okuryazarlık Düzeylerini ve Etkileyen Faktörleri Belirleme. Uzmanlık Tezi, 2017. İstanbul Üniversitesi, İstanbul. [CrossRef]

36. Tayhan A. Kırk yaş ve üzeri erkeklerin prostat kanseri taramalarına yönelik bilgi düzeyleri ile sağlık okuryazarlıkları arasındaki ilişki. Uzmanlık Tezi, 2016. Celal Bayar Üniversitesi, Manisa. [CrossRef]

37. Ş̧en UğurVY.Manisa Şehzadeler Eğitim Araştırma Toplum Sağlığı Merkezi Bölgesinde Erişkinlerde Sağlık Okuryazarlığı Düzeyinin Belirlenmesi. Uzmanlık Tezi, 2016. Celal Bayar Üniversitesi, Manisa. [CrossRef]

38. Robert $E$, Dramaix $M$, Swennen B. Vaccination coverage for infants: crosssectional studies in two regions of Belgium. Biomed Res Int 2014;2014:1-7. [CrossRef]

39. Özdemir Y. Aile Sağığı Merkezlerine Başvuran Hastaların Sağlık Okuryazarlık Düzeylerinin Belirlenmesi: Kahramanmaraş ili Örneği. Yüksek Lisans Tezi, 2018. Hacettepe Üniversitesi, Ankara. [CrossRef]

40. Öncü E, Vayısoğlu S, Güven Y, Aktaş G, Ceyhan H, Karakuş E. Hipertansiyonu olan bireylerin kronik hastalık yönetimine ilişkin değerlendirmeleri ve sağlık okur-yazarlığı ile ilişkisi. Anatol JFM 2018;1:31-2. [CrossRef] 